\title{
THE VALUATION OF TAX SHIELDS INDUCED BY ASSET STEP-UPS IN CORPORATE ACOUISITIONS
}

\author{
Alexander P. Groh \\ Christoph Henseleit
}


The CIIF, International Center for Financial Research, is an interdisciplinary center with an international outlook and a focus on teaching and research in finance. It was created at the beginning of 1992 to channel the financial research interests of a multidisciplinary group of professors at IESE Business School and has established itself as a nucleus of study within the School's activities.

Ten years on, our chief objectives remain the same:

- Find answers to the questions that confront the owners and managers of finance companies and the financial directors of all kinds of companies in the performance of their duties

- Develop new tools for financial management

- Study in depth the changes that occur in the market and their effects on the financial dimension of business activity

All of these activities are programmed and carried out with the support of our sponsoring companies. Apart from providing vital financial assistance, our sponsors also help to define the Center's research projects, ensuring their practical relevance.

The companies in question, to which we reiterate our thanks, are:

Aena, A.T. Kearney, Caja Madrid, Fundación Ramón Areces, Grupo Endesa, Royal Bank of Scotland and Unión Fenosa.

http://www.iese.edu/ciif/ 



\title{
THE VALUATION OF TAX SHIELDS INDUCED BY ASSET STEP-UPS IN CORPORATE ACOUISITIONS
}

\author{
Alexander P. Groh ${ }^{1}$ \\ Christoph Henseleit ${ }^{2}$
}

\begin{abstract}
We derive discount rates for depreciation and amortization tax shields resulting from asset step-ups in corporate mergers and acquisitions. By assigning all relevant sources of uncertainty for such tax shields and by accounting for corporate debt it is shown that for APV valuations $\mathrm{r}^{*}$, a rate between the firm's cost of debt and the risk-free rate, is adequate to discount step-up induced depreciation benefits. When the benefits are valued on a standalone basis, the adequate discount rate is the after-tax weighted average of $r^{*}$. Discount rates for these shields have been determined arbitrarily in empirical research on corporate acquisitions so far. However, they are found to be in line with the rates deduced in this paper.
\end{abstract}

JEL Classification: G12, G34

Keywords: Tax Shield, Step-up Depreciation, Valuation.

\footnotetext{
${ }^{1}$ Visiting Professor, Finance, IESE and GSCM, Montpellier Business School

${ }^{2}$ Bain \& Company, Munich
} 


\section{THE VALUATION OF TAX SHIELDS INDUCED BY ASSET STEP-UPS IN CORPORATE ACOUISITIONS}

\section{Introduction}

Borrowing is not the only instrument that shields corporate income against taxes. Apart from interest payments expenses for inventory, depreciation and amortization play a major role in determining the corporate tax liability. Asset step-up induced depreciation and amortization tax shields are created in the framework of corporate mergers and acquisitions. ${ }^{1}$ Asset step-ups allow the acquirer to increase (step-up) the pre-acquisition tax basis of acquired assets to the fair market value or the purchase price. The stepped up tax basis is fully depreciable/amortizable and thus provides additional tax shields, and hence value, for the combined entity after the transaction.

In his empirical study of tax value in management buyouts, Kaplan (1989) estimates that for the companies in his sample, which chose to step-up the asset basis, the median value of the asset step-up is approximately 30\% of the premium paid. ${ }^{2}$ To derive these figures, Kaplan (1989) examines a sample of 76 management buyouts of publicly held companies completed in the period from 1980 to 1986. However, the Tax Reform Act of 1986 has reduced tax benefits of asset step-ups in mergers and acquisitions. Nevertheless, asset step-up structured transactions still occur on a regular basis, in particular for acquisitions of corporate subsidiaries and S corporations. Still, asset step-ups can contribute a significant amount of value in the context of corporate acquisitions. As Erickson and Wang (2000) note, Cox Communications could generate asset step-ups worth about $\$ 350$ million when it acquired the cable television business of Gannett Company for \$2.7 billion in 1999. ${ }^{3}$ In their analysis, Erickson and Wang (2000) also find (at least) weak evidence that deal premiums in acquisitions of subsidiaries are higher in the case that the deal is structured in a way enabling assets to be stepped up, thus indicating the additional value of asset step-ups. Moreover, Maydew et al. (1999) note that the value of asset step-ups is regularly evaluated by sellers in the context of divestitures of corporate subsidiaries in order to

\footnotetext{
${ }^{1}$ In this paper, for convenience, we use the terms "depreciation benefits" or "depreciation tax shields" as shorthand for benefits or tax shields induced by depreciation and amortization.

233 out of the 76 companies elected to step up the asset basis, and 30 out of those 33 generated a positive value for the asset step-up. The 30\% of the transaction price relates to these 30 companies. Furthermore, the value of 30\% of the purchase price is net of costs for the asset step-up. Nevertheless, it is important to mention that, in Kaplan's analysis, the benefit of the asset step-ups is much smaller than the benefit of interest deductions.

${ }^{3}$ Source, as quoted by Erickson and Wang (2000), p. 60: Cox Communications, Inc. 8-K dated July, 1999.
} 
outline this information in the sales materials provided to potential buyers. ${ }^{4}$ Accordingly, the valuation of asset step-up induced depreciation tax shields via appropriate discount rates is a fundamental issue in the context of mergers and acquisitions.

To our knowledge, there is no consistent approach in corporate financial literature to value the tax shields of asset step-up based depreciations. Not even a practical model of how to determine appropriate discount rates for these tax shields can be found. Indeed, some empirical studies dealing with tax effects in corporate acquisitions use specific rates to discount asset step-up induced depreciations. However, those studies do not derive such rates via analyses, but determine them arbitrarily. The contribution of this paper is to discuss all relevant parameters and to provide a consistent approach for the derivation of these discount rates. We start with the risk-less aftercorporate tax interest rate, which is, according to Ruback (1986), the appropriate rate to discount risk-less after-tax corporate cash flows, such as "regular" depreciation benefits. Ruback (1986) assumes depreciation tax shields to be free of risk. By dissolving Ruback's assumptions, we derive corresponding discount rates via a case differentiation. For valuations conducted in the framework of the Adjusted Present Value approach we show that a discount rate $\mathrm{r}^{*}$ is adequate to value step-up induced depreciation benefits. In the case that the valuation of the tax shield of asset step-ups is not conducted via the Adjusted Present Value approach, the tax advantage of debt is not accounted for in a separate term and thus has to be included in the discount rate of the cash flows to be valued. When accounting for its debt tax benefit the depreciation tax shield can also be valued standalone, without being integrated into the entire valuation for the firm. (The latter valuation setting will be referred to as standalone valuation in the rest of this paper.) Accordingly, the adequate discount rate is the after-tax weighted average of $r^{*}$, where the weight is determined by the targeted capital structure of the merged entity. The rate $\mathrm{r}^{*}$ is between the firm's cost of debt and the risk-free rate. The derived rate has to be used in combination with Graham's (1996a) simulated marginal tax rates; i.e., the tax shields to be discounted by these rates have to be calculated by means of Graham's (1996a) tax rates to result in a consistent valuation of tax shields induced by asset step-ups in corporate acquisitions. A comparison of the discount rates proposed in this paper with the rates determined arbitrarily by the authors of some empirical studies on step-up depreciation induced tax shields shows that their chosen rates are in line with our derivation.

The rest of the paper is organized as follows. Section 2 provides a literature review regarding the derivation of discount rates for asset step-up induced depreciation benefits. Section 3 deals with the tax accounting for depreciation and amortization tax shields created in the framework of corporate acquisitions. The general concept of asset step-ups is introduced and the procedures for calculating asset step-up induced depreciation and amortization are described. Next, we discuss the tax advantageousness of transactions with asset step-ups in Section 4. In Section 5 we describe our approach to derive an appropriate discount rate for asset step-up induced depreciation and amortization tax benefits. Section 6 concludes.

\section{Literature Review}

Unlike debt tax shields, neither finance textbooks nor related research papers deal with the problem of deriving discount rates for asset step-up induced depreciation benefits. The only topic where indications for the utilization of such rates can be found is in empirical studies of corporate acquisitions. Auerbach and Reishus (1986) analyze the tax consequences of mergers and

\footnotetext{
${ }^{4}$ As a source Maydew et al. (1999) refer to several discussions with M\&A advisors.
} 
acquisitions. In their study they note that, in order to value the tax incentives of two firms to merge, future saved tax payments which evolve in the case of a merger have to be valued via an appropriate discount rate. In fact, step-up induced depreciation benefits are a possible source for such savings. By explicitly using the term "appropriate", Auerbach and Reishus (1986) imply that a discrete discount rate has to be derived for this kind of flow. In his study of the value of taxes in management buyouts, Kaplan (1989) argues that, when increased depreciations created by stepping up the asset basis are risk-less, the after tax cost of debt is the adequate discount rate. Since these flows are subject to both risks - the tax rate uncertainty and the uncertainty of utilizing the deductions - he finally quantifies the corresponding discount rate arbitrarily as being either 10\% or 15\%. Schipper and Smith (1991) investigate how management buyouts affect corporate interest and depreciation tax benefits. When quantifying the benefits of estimated step-up induced depreciations, they employ "reasonable" discount rates of 5\% to 10\%, without commenting on the derivation or the use of the word "reasonable". Erickson (1998) analyses the consequences of taxes on the structure of corporate acquisitions. In this framework he calculates the present value of additional tax benefits from asset step-ups at a discount rate of 12.5\%. He also mentions that he derives similar results for the value of the step-up when using a discount rate of $10 \%$, but slightly varying depreciation periods. Unfortunately, he does not justify the derivation of these figures. In their study of the tax impact on the structure of a corporate divestiture, Maydew et al. (1999) use a discount rate of $10 \%$ to value the tax benefits induced by additional asset step-up-based depreciations. As with Erickson (1998), Maydew et al. (1999) do not provide any rationale of how they derive this discount rate. Erickson and Wang (2000) explore the effect of transaction structures on the premiums paid in subsidiary sales. When assessing the average value of one dollar of asset step-up they use an after tax discount rate in the 10\% range. ${ }^{5}$ Modeling the effect of the organizational form of the target on price and tax structure of the acquisition, Erickson and Wang (2005) also compute the present value of the tax savings from stepping up the tax basis. Depending on the useful life of the respective assets they use 7\% or 10\% as an "appropriate" discount rate. Although Erickson and Wang (2005) do not substantiate these figures directly, they add an alternative reasoning: analyzing their set of transactions it turns out that, in several cases, acquirers do report an estimate of their generated tax benefit's present value. Based on the acquirers' disclosures, Erickson and Wang (2005) calculate the corresponding discount rates to be in 7\%-9\% range.

It is material to indicate that none of the mentioned empirical studies put any emphasis on the derivation/determination of discount rates for asset step-up induced depreciation benefits. Apart from Kaplan (1989), who briefly thinks about corresponding risks, each study only briefly touches depreciation benefit's discount rates. Summarizing, there is no consistent approach in corporate financial literature to value the tax shields of asset step-up based depreciations. The contribution of this paper is to provide a consistent approach to derive such rates.

\section{Relevant Tax Aspects of Asset Step-ups}

The following two sections introduce essential tax aspects that are important in the framework of valuing step-up induced depreciation tax shields. First, we introduce the concept of asset step-ups in corporate acquisitions and describe how the absolute amount of step-up induced depreciation and amortization is calculated.

\footnotetext{
${ }^{5}$ This range for the discount rate is determined under the assumption of a 35\% corporate tax rate and an average depreciation/amortization period of 10-15 years; see Erickson and Wang (2000), p. 81.
} 
Asset step-ups are created in the framework of corporate mergers and acquisitions. Simplified, when the acquirer purchases the assets of the target, the buyer can increase (step-up) the preacquisition tax basis of acquired assets to the fair market value or the purchase price. The stepped-up tax basis is fully depreciable/amortizable. From a pre-tax view, depreciation and amortization are cash neutral; that is, a higher level of depreciation or amortization only reduces pre-tax profits, not pre-tax cash flows. However, depreciations and amortizations impact the value of a firm, since they are tax deductible. When calculating the federal income tax liability of a corporation, depreciations/amortizations can be applied as deductions from gross income thus reducing taxable income. Consequently, the corporate tax burden is reduced by the additional depreciation amount times the tax rate, hence increasing after-tax cash flows and company value. ${ }^{6}$ The total tax effective asset step-up consists of step-up allocable to inventory, depreciable tangible assets and amortizable intangible assets rather than land or other non-amortizable assets. Note that depreciation/amortization benefits of asset step-ups usually only come at a cost: the seller realizes a gain, since he sold his assets above book value, with this gain being taxed at the corporate tax rate. The seller's cost in turn increases the purchasing price for the buyer, as the burden of the tax is shared between acquirer and target. For most deal structures, costs of asset step-ups outweigh the depreciation benefits. ${ }^{7}$ Nevertheless, acquisitions may also be carried out via deal structures that yield higher costs than the benefits of asset step-ups, since there may be non-tax issues favoring a certain transaction structure. ${ }^{8}$ Correspondingly, step ups occur despite the specified costs and thus have to be valued in the framework of a corporate acquisition. If step-ups are available at a tax advantage for the seller or the buyer, then their valuation becomes even more important.

Asset step-ups can only be achieved in taxable acquisitions. Simplifying, acquisitions are taxable when the form of consideration is cash. When the form of consideration is stock, the acquisition is tax-free. There are basically two alternative deal structures of taxable acquisitions which enable the acquirer to step-up the asset base. Either the buyer purchases the target's assets, or the buyer purchases the stock of the target and, in accordance with I.R.C. Section 338, elects to treat the acquisition of shares as if assets were acquired. For that case the transaction is being taxed as if it were an asset sale. ${ }^{9}$

Next, the calculation of asset step-ups and related tax benefits has to be discussed. Briefly, the procedure consists of three steps. The starting point is the determination of the new total tax basis of all acquired assets. Thereon, this basis has to be allocated to particular assets which are grouped into seven asset classes. Finally, corresponding immediate deductions, depreciations and amortizations are to be calculated.

\footnotetext{
${ }^{6}$ In the United States, tax accounting is defined by the regulations of the Internal Revenue Code (IRC) which sets up a proprietary accounting system. In American tax accounting there are two methods to determine income: the cash method and the accrual method. While mainly individuals utilize the cash method, the accrual method normally applies for corporations. The determination of taxable income of the accrual method basically relies on the principles of financial accounting, but is modified by IRC regulations.

${ }^{7}$ As stated by Kaplan (1989), p. 612, and Scholes, Wolfson, Erickson, Maydew, and Shevlin (2002), p. 320. For more details regarding the net tax benefits of step-ups please refer to Section 4.

${ }^{8}$ According to Scholes, Wolfson, Erickson, Maydew, and Shevlin (2002), p. 323, there are four major non-tax issues in this context: costs of financial reporting, such as adverse earnings effects; contingent liabilities; managerial issues, as for example a possible dilution of ownership in case of a mainly managerially-owned buyer purchasing the stocks of the seller; and finally transaction costs.

${ }^{9}$ In the case that the purchased entity is a corporate subsidiary, the buyer and the seller can, according to Section 338(h) (10), jointly elect to treat the share deal as an asset deal.
} 
The calculation of the acquired asset's new tax basis differs with respect to the deal structure. The basic principle is to value the new tax basis according to its fair market value. In the case of an asset acquisition this simply relates to the purchasing price. In the case of a share deal with I.R.C. Section 338 election it is slightly more complicated to calculate the fair market value of the assets. As described by I.R.C. Section 338(b), the basis to be allocated is the "adjusted grossed up basis" (AGUB), which mainly consists of three parts: the first component is the grossed-up basis of the recently purchased stock. If there are no outside shareholders (except for the acquirer), there is no need for grossing up. In such a case the basis of the acquired stock already is the first component. If there are outside shareholders, the basis of the purchased shares has to be grossed up via division by the portion of actually acquired stocks. ${ }^{10}$ The second part is the acquirer's basis in its non-recently purchased stock of the target. The acquirer has an option to step-up this basis analogous to the basis gross-up of the recently purchased stock. ${ }^{11}$ The final component of AGUB is the liabilities of the target. Since, in most of the cases financing also includes debt, I.R.C. Section 338(b) (2) prescribes the adjustment for liabilities. Moreover, the acquirer's costs of purchasing the target's assets or stock is accounted for independently from the acquisition structure, as those costs are capitalized into the price paid for the assets; respectively into the basis of that stock.

The allocation of the new tax basis is carried out identically for asset and share deals with I.R.C. Section 338 election. For asset deals the residual valuation approach under I.R.C. Section 1060 defines how the purchase price is allocated among the acquired assets. In fact, I.R.C. Section 1060 refers to the rules of I.R.C. Section 338(b) (5); the relevant section for share deals with I.R.C. Section 338 election, which provides that AGUB must be allocated pursuant to regulations. ${ }^{12}$ The allocation is carried out in seven asset classes. First, the purchasing price/AGUB is allocated to cash and cash equivalents to the extent of its face value (Class I). Next, marketable securities, certificates of deposit, government securities, foreign currencies, etc. (Class II) are allocated. Subsequently, allocation proceeds to receivables (Class III), inventory (Class IV), fixed assets (Class V), and then to intangible assets, such as formulas, plans, and customer lists (Class VI). For Classes II-VI the allocation occurs in proportion to (but not in excess of) the fair values of the assets. Eventually, the remainder of the purchase price is allocated to goodwill and going concern value. $^{13}$ As the corresponding depreciation/amortization schedules are different, the allocation of the additional tax basis to the seven classes is essential.

By means of the acquisition, the tax bases of inventory, depreciable tangibles and certain intangibles of the acquired entity can be increased. Costs for inventory can be deducted in the period the inventory is consumed. Accordingly, depending on the inventory turnover, the

\footnotetext{
${ }^{10}$ For example, if $80 \%$ of the target's stock is acquired for $\$ 1$ billion during the acquisition period of twelve months, the grossed up basis is $\$ 1.25$ billion (as calculated via $\$ 1$ billion/80\%).

${ }^{11}$ Same situation as in Footnote 10. 20\% of the target's shares have been purchased prior to the acquisition with a basis of $\$ 200$ million. The basis of non-recently purchased stock can be increased to $\$ 250$ million (as calculated via $\$ 1$ billion/80\%*20\%). In the case of a subsidiary acquisition with an election corresponding to Section 338(h) (10), this gross-up is mandatory.

12 Prior to the Tax Reform Act of 1986, the parties involved in an asset acquisition could bargain an allocation of the purchase price. When the parties were bargaining in adverse tax positions, the allocation so agreed upon was normally accepted by the IRS. After the act an agreement among the parties as how to determine the fair values of acquired assets is still accepted, as long as the allocation is not explicitly contrary to the residual method.

${ }^{13}$ For further details regarding the allocation of purchase price/AGUB refer to Ginsburg and Levin (2001) Vol.1, Chapter 403 or Bittker and Eustice (2000), Chapters 10.40 and 10.43.
} 
additional amount of tax deductible inventory created by the acquisition does not have to be discounted. Discount rates have to be derived for the additional amounts of depreciable tangible and tax amortizable intangible assets. Correspondingly, the next two paragraphs cover the determination of the additional step-up induced amounts of depreciation and amortization.

The portion of the additional tax basis allocated to Asset Class V can be depreciated by using the modified accelerated cost recovery system (MACRS). The MACRS, which was designed in the context of the TRA 1986, is a substantially revised version of the accelerated cost recovery system (ACRS), which was implemented as part of the Economic Recovery Act in 1981. Note that (M)ACRS rules are not designed to optimize the determination of taxable income, but to stimulate the economy. According to I.R.C. Section 168(a) MACRS applies to most tangible depreciable assets, regardless of whether acquired new or used. The application is mandatory. ${ }^{14}$ In a first step, the useful life of the asset has to be assessed. Then, according to I.R.C. Section 168(e) (1), the property is assigned to one of several property classifications. Each classification is assigned a certain recovery period; the time over which the property gets depreciated. In most cases recovery periods are significantly shorter than useful lives. Salvage values do not exist in the framework of MACRS. The value of the property is depreciated to zero during the recovery period. While most personal property is assigned to recovery periods of three, five or seven years, nearly all depreciable real property has recovery periods of either 27.5 or 39 years. The depreciation method to be applied depends on the respective property classification. Depreciable real property only qualifies for straight-line depreciation. Personal property classified into the classes of 3-year, 5-year, 7-year and 10-year recovery periods is eligible for the $200 \%$ declining balance method, with a mandatory switch to straight-line depreciation from that year on when the straight-line method yields a higher depreciation amount than the 200\% declining method. Property with 15-year and 20-year recovery periods qualify for the 150\% declining balance method, with the same mandatory switch to the straight-line method. ${ }^{15}$

I.R.C. Section 197 organizes the amortization rules of goodwill and certain other intangibles created in the context of corporate acquisitions. Accordingly, "Section 197 intangibles" may be amortized over a period of 15 years beginning with the month the respective asset is acquired. Note that this section remains inapplicable in the case that intangibles are self-created by the firm. It only applies to assets that are acquired by the firm in the framework of the conduct of a trade or business or an activity engaged in for the production of income. The term "Section 197 intangible" comprises various intangibles, such as goodwill, going concern value, information base, patents, copyrights, etc. It does not comprise financial interest, land or computer software. ${ }^{16}$ However, Classes VI and VII, to which additional tax basis value might be allocated, only contain "Section 197 intangibles". Thus, the separation between "Section 197 intangibles" and "Non Section 197 intangibles" is only relevant with respect to the step-up allocation and not with respect to the determination of step-up induced amortizations. Section 197 was

\footnotetext{
${ }^{14}$ In some exceptional cases property may be depreciated under the unit-of-production method. For those cases I.R.C. Section 167 applies.

15 The 200\%/150\% declining balance method yields a depreciation rate of two times/1.5-fold of the straight-line method rate (based on the remaining years of the recovery period). For further details regarding depreciation regulations, for example concerning elective alternatives for the depreciation method, the half-year convention or special depreciation rules on personal property implemented recently in the framework of I.R.C Sections 168(k) and 179 refer to Freeland, Lathrope, Lind, and Stephens (2004), Chapter 14.

${ }^{16}$ For a detailed listing of "Section 197 intangibles" refer to I.R.C. Section 197(d); for a listing of intangibles which are not considered as "Section 197 intangibles" refer to I.R.C. Section 197(e).
} 
introduced in 1993 in the context of the Omnibus Reconciliation Act (ORBA). Congress enacted this section to simplify the law and to define a single proceeding and timeframe regarding the cost recovery of most acquired intangibles. Before 1993, goodwill and many other types of intangibles were not amortizable for tax purposes. ${ }^{17}$

Having considered all relevant aspects for the calculation of step-up induced depreciation and amortization tax shields, we analyze in the next section whether asset step-up structured acquisitions yield a net tax advantage or a relative tax advantage compared to acquisitions without asset step-ups.

\section{Tax Benefits of Asset Step-ups}

Assets can only be stepped up in the framework of taxable acquisitions. For structuring taxable acquisitions there are two major scenarios. Either the acquirer takes a stepped up tax cost basis in the assets of the target, or the target's current cost basis carries over to the acquirer without a step-up. As mentioned above, assets may be stepped up in the context of asset acquisitions or stock acquisitions with I.R.C. Section 338 election (if the target is a $\mathrm{S}$ corporation or a corporate subsidiary, I.R.C. Section 338(h) (10) election applies). Such elections always result in the transactions being taxed as if the buyer purchased the assets of the respective target. In the case of a step-up enabling deal structure with the purchase price/AGUB being above the current tax basis of the target's assets, there is a tax liability for the target based on the gain in asset appreciation. ${ }^{18}$ Moreover, other major tax attributes, such as net operating losses (NOLs) or tax credits, do not carry over to the buyer. If a taxable transaction is structured as a share deal without a corresponding election, the tax basis of the target's assets carries over and the tax attributes survive. In order to determine whether a step-up deal comes with a tax benefit, the financial analyst needs to understand the gain taxes impose when the purchase price outbalances the tax basis of the target's assets. The way this gain is taxed depends on the nature of assets acquired. If depreciable property is sold at a profit a capital gain is yielded, except to the extent of past depreciation, which has to be recaptured as ordinary income. If sold at a loss this property yields an ordinary loss. Inventory and accounts receivable sold at a profit also yield ordinary income. Other assets, such as stock held for investment, result in capital gains or capital losses. The distinction between ordinary income and capital gains does not matter on the corporate level, since on the corporate level top statutory tax rates for both capital gains and ordinary income are $35 \%$. For individuals these rates are different (15\% for capital gains, 35\% for ordinary income). In order to qualify the benefits of asset step-ups in the framework of taxable acquisitions, this paper analyses two questions: does the asset step-up deal come with a net tax benefit when compared to the alternative of no acquisition? Do acquisitions including an asset step-up yield a relative tax benefit compared to the alternative deal-scenario involving a carryover of the asset basis? To answer these questions we differentiate three cases: the target being a freestanding $\mathrm{C}$ corporation, a corporate subsidiary, or an S corporation.

\footnotetext{
${ }^{17}$ For more details regarding the tax treatment of intangible assets, in particular regarding exclusions of certain intangible assets under special circumstances please refer to Ginsburg and Levin (2001) Vol.1, Chapter 403.

${ }^{18}$ In the case of a stock acquisition of a C corporation with Section 338 election, the tax liability is imposed on the acquirer. Accordingly, the purchase price the buyer is willing to pay for the shares of the target reduces by the amount of these taxes payable. For further details regarding the tax effects of deals with Section 338 elections please refer to Scholes, Wolfson, Erickson, Maydew, and Shevlin (2005), Chapter 14.
} 
For acquisitions of freestanding $\mathrm{C}$ corporations, the tax effect of an asset step-up is most probably negative. If the assets of a target are sold, or deemed sold in case of a share deal with Section 338 election, for a price that is higher than the asset's tax basis, a gain is realized. This gain is taxed immediately at the corporate level. This taxable gain does not occur if the deal is structured by means of a stock acquisition without election. The main aspect in this context is that the present value of the combined entity's asset step-up is negative. While the stepped up amount has to be depreciated over time, thus delaying the corresponding tax effect of an increased asset base, the capital gain and ordinary income resulting from the step-up is taxed immediately. This straightforward interrelation has also been confirmed empirically by Erickson (1998). ${ }^{19}$ Hence, both posed questions have to be answered with a "no". However, including further tax attributes, for example NOLs, into the analysis might alter the situation. In the case that the target corporation has NOLs, these NOLs can be used at once to offset the taxable gain; the NOLs of the acquirer cannot be used for offsetting. If the target's amount of NOLs is outstandingly high, the present value of the step-up induced tax benefits might outweigh taxes payable on the asset appreciation, resulting in a positive net tax effect. If the deal is structured as a share deal without Section 338 election, the NOLs of the target carryover to the buyer. But, depending on the profitability of the acquirer, they are only usable over time. Correspondingly, the target's NOLs may make the basis-step-up transaction structure more efficient with regard to taxes than the basis-carryover structure. Prior to the Tax Reform Act of 1986, only ordinary income associated with the step-up of the target's assets tax basis was taxed, while any capital gains were not subject to taxation. The inclusion of taxes to capital gains, achieved via stepping up the tax basis of the target, significantly changed the tax consequences of taxable mergers and acquisitions. However, even before the TRA 1986, step-ups were not occurring as often as commonly believed. Before 1986 only 17\% of the largest acquisitions came with a step-up of the target's assets. ${ }^{20}$ These days, most acquisitions of freestanding $\mathrm{C}$ corporations are structured as stock acquisitions, ${ }^{21}$ which do not come with an asset step-up and the corresponding taxable gain at the corporate level. ${ }^{22}$

For acquisitions of corporate subsidiaries, which comprise an economically significant portion of the M\&A market, ${ }^{23}$ the situation is different. If the assets/stocks of a corporate subsidiary are sold at a higher value than the net tax basis of its assets/stocks a taxable gain is generated on the corporate level. The corresponding tax is payable by the subsidiary (in the case of asset acquisition) or the parent (in the case of stock acquisition). Provided that the parent's tax bases in the subsidiaries' shares and assets are equally high, the tax burden is the same for both deal structures. ${ }^{24}$ But an asset step-up is only available in the framework of an asset deal or a share deal with I.R.C. Section 338(h) (10) election. Correspondingly, there is an incremental tax benefit for asset step-up-structured acquisitions relative to the alternative stock acquisition without election. This view is confirmed by Erickson and Wang (2000). In their empirical study of acquisition premiums in subsidiary sales, they find weak evidence for higher premiums in

\footnotetext{
${ }^{19}$ See Erickson (1998), p. 281.

${ }^{20}$ As noted by Scholes, Wolfson, Erickson, Maydew, and Shevlin (2002), p. 322, Footnote 12.

${ }^{21}$ See Erickson (1998), p. 295, Footnote 17.

${ }^{22}$ For more details regarding tax differences of stock- and asset deals of freestanding C corporations refer to Scholes, Wolfson, Erickson, Maydew, and Shevlin (2005), Chapter 14.

${ }^{23}$ See Erickson and Wang (2000), p. 62.

${ }^{24}$ However, Erickson and Wang (2000) note that a divesting parent's basis in its subsidiary's assets is frequently lower than the basis in the assets of the subsidiary.
} 
transactions going with I.R.C. Section 338(h) (10) election rather than without the election. Again, there is no net tax benefit to the step-up transaction when compared to the no-deal alternative. The ratio corresponds to the rationale in the previous paragraph: while the step-up induced amounts of depreciation can only be realized over time, the gain resulting from the step-up has to be taxed immediately. The treatment of NOLs for subsidiary sales is analogous to that in the previous paragraph.

$S$ corporations are numerous in the United States. With respect to large and medium-sized firms, there are 50\% more S corporations than C corporations. ${ }^{25}$ When analyzing step-up induced tax benefits in deal structures involving acquisitions of $\mathrm{S}$ corporations, the distinction between ordinary income and capital gains is crucial, since the top statutory tax rates for these gains are different at the individual level (15\% for capital gains, 35\% for ordinary income). If the transaction is structured as an asset acquisition or stock acquisition with I.R.C. Section 338(h) (10) election, gains/losses are recognized at the corporate level. However, there is no tax liability for the target corporation, as the $\mathrm{S}$ corporation is a conduit entity, passing through taxable gains to the shareholders. The shareholder's tax liability depends on whether the recognized gains are capital in nature or instead ordinary income. For stock acquisitions without I.R.C. Section 338(h) (10) election, gains/losses are always capital in nature and are recognized directly at the shareholder level of the target. The asset step-up is only available for the first two structures. Whether these step-ups come with a net or with a relative tax benefit is not obvious. It depends on the proportion of the total step-up amount subject to ordinary income versus capital gains. If these deal structures only result in capital gains (for example if the accumulated depreciation of all assets is zero) there is a relative tax advantage over share deals without I.R.C. Section 338(h) (10) election. Furthermore, even a net tax benefit is possible. This depends on the resulting depreciation schedules and the magnitude of the discount rate for the step-up induced depreciation benefits. The higher the proportion of ordinary income to the total gain for the step-up deal structures, the less attractive the step-up structure. In their empirical study of the effect of organizational form on acquisition price, Erickson and Wang (2005) find evidence for the relative tax advantage of step-up creating transaction structures in acquisitions of $\mathrm{S}$ corporations. Moreover, they find that premiums are generally higher for acquisitions of $\mathrm{S}$ corporations than for acquisitions of $\mathrm{C}$ corporations.

In conclusion, it should be emphasized that asset step-ups are not as important as they were before TRA 1986. Nevertheless, asset deals are still a significant aspect of corporate acquisitions, in particular for acquisitions of corporate subsidiaries and S corporations. But for acquisitions of $\mathrm{C}$ corporations step-up inducing transaction structures may also be preferable, as various non-tax issues may be the driving factor for the deal structure decision. Accordingly, asset step-ups do occur, independent of the respective tax advantageousness. Hence, the valuation of step-ups via appropriate discount rates is a fundamental issue in the framework of corporate acquisitions. The next section is concerned with the derivation of such discount rates.

${ }^{25}$ See Scholes, Wolfson, Erickson, Maydew, and Shevlin (2005), Chapter 16. 


\section{Discount Rates for Asset Step-up Induced Depreciation Tax Shields}

\subsection{Basic Principles}

In this sub-section we discuss the fundamentals for the derivation of appropriate discount rates for step-up induced depreciation benefits. In financial theory the discount rate has to reflect the risk of the flow to be valued. The risk characteristics of step-up induced depreciation benefits are unique. The depreciations are fixed once the assets are stepped up, but future income fluctuates, tax rates might change and default risk is omnipresent. Accordingly, it is material to derive an adequate discount rate. For the valuation of the step-up induced tax benefits, two alternative approaches are meaningful: a standalone valuation, which only calculates the net present value of the tax shield by applying a discount rate which includes the tax benefit of debt with respect to the financing mix, or a valuation via an additional term in the framework of the Adjusted Present Value method (Meyers, 1974), where the debt tax benefit is already accounted for in the second term of the APV-Formula. The Adjusted Present Value method has been gaining importance in the recent past, not only among theorists, but also for practitioners. ${ }^{26}$ Due to the principle of value additivity, the APV is a very flexible tool for managers, enabling them to divide the valuation problem into several pieces that make managerial sense. Furthermore, additional sources of value, other than corporate operations and leverage, can be included into the analysis. For example, depreciation benefits that arise in the context of asset step-up structured acquisitions can be incorporated into the valuation. Under the assumption that the additional tax shield is available at a cost of zero, the APV-Formula to calculate the value of an acquired firm can be extended to:

$$
V_{E V}=\sum_{t=1}^{T} \frac{E\left(F C F_{t}\right)}{\prod_{i=1}^{t}\left(1+r_{i}\right)}+\sum_{t=1}^{T} \frac{E\left(C T S_{t}\right)}{\prod_{i=1}^{t}\left(1+r_{C T S_{i}}\right)}+\sum_{t=1}^{T} \frac{E\left(D T S_{t}\right)}{\prod_{i=1}^{t}\left(1+r_{D T S_{i}}\right)}
$$

where:

\begin{tabular}{|c|c|c|}
\hline$V_{E V}$ & $=$ & Value of the firm at present \\
\hline FCF & $=$ & $\begin{array}{l}\text { Free after-tax cash flow of the acquired operating business, calculated as if it } \\
\text { was all equity financed }\end{array}$ \\
\hline$r$ & $=$ & Operating cost of capital of the combined entity \\
\hline CTS & $=$ & Debt tax shield \\
\hline$r_{C T S}$ & $=$ & Discount rate for the debt tax shield \\
\hline DTS & $=$ & Tax shield due to depreciation/amortization of the asset step-up \\
\hline$r_{D T S}$ & $=$ & Appropriate discount rate for the $D T S$ of the combined entity \\
\hline$t$ & $=$ & Period \\
\hline$T$ & $=$ & $\begin{array}{l}\text { Forecast horizon (assuming either a final payoff or continuing values for the } \\
\text { three terms of the equation) }\end{array}$ \\
\hline
\end{tabular}

\footnotetext{
${ }^{26}$ Inselbag and Kaufold (1989), p. 87 stress the increased popularity of the APV technique, especially among theorists. This view is affirmed by Inselbag and Kaufhold (1997), p. 114. Luehrmann (1997), p. 135 emphasizes that the APV is also increasingly applied in professional companies.
} 
The idea to consider the value of the asset step-up within the context of the APV-formula is based on Locke (1990) and Tirtiroğlu (1998), who separately account for the value of depreciation-based tax shields in the framework of property evaluation.

To be entirely accurate we would have to derive an appropriate discount rate for each future period in which step-up induced depreciation benefits occur. As in corporate valuation practice, the approach of this paper is to use one discount rate for the entire forecast period. We start with the risk-less after-corporate tax interest rate, which is, according to Ruback (1986), the appropriate discount rate to value risk-less after-tax corporate cash flows (Ruback assumes depreciation tax shields to be free of risk). ${ }^{27}$ Ruback (1986) analyzes the market value of riskless after-corporate-tax cash flows via an arbitrage approach. By issuing risk-less debt a firm can precisely offset the value of a risk-less after-tax future cash flow when incorporating the interest deductibility of debt into the financing schedule. ${ }^{28}$ Ruback's arbitrage approach shows that a risk-less after-tax cash flow $\mathrm{CF}_{\mathrm{T}}$ to be realized in the future period $\mathrm{T}$ can be valued with the after-corporate-tax rate of risk-free return: ${ }^{29}$

$$
V\left(C F_{T}\right)=\frac{C F_{T}}{\left(1+r_{f}(1-\tau)\right)^{T}}
$$

where:

$$
\begin{array}{lll}
r_{f} & = & \text { The risk-free rate of return } \\
\tau & = & \text { The corporate tax rate }
\end{array}
$$

Ruback (1986) explicitly refers to depreciation tax shields as being risk-less cash flows whose market value can be determined via this rate. ${ }^{30}$ Moreover, Kaplan (1989) makes use of Ruback's discount rate in his empirical study about taxes as a source of value in management buyouts. His (brief) approach of deriving adequate discount rates for step-up induced depreciation benefits is based on Ruback's after-tax cost of (risk-less) debt. ${ }^{31}$ Concluding, Ruback's discount rate has been designed and applied for the valuation of depreciation-induced tax benefits, and thus is an appropriate starting point for the analysis in this paper.

\footnotetext{
${ }^{27}$ See Ruback (1986), p. 327.

${ }^{28}$ For a detailed derivation of this arbitrage approach to determining the discount rate of risk-less after tax cash flows, refer to Ruback (1986), p. 326.

${ }^{29}$ See Ruback (1986), Equation 2.

30 See Ruback (1986), p. 327. Note that the depreciation tax shields that Ruback mentions are the tax benefits that stem from conventional asset depreciation of the firm, while the specific depreciation tax shields examined in this paper are asset step-up induced in the framework of corporate acquisitions via an asset deal structure.

31 See Kaplan (1989), p. 619. Actually, Kaplan bases his approach to deriving an adequate discount rate for the step-up induced depreciation benefits on the after-tax cost of debt rather than on the after-tax cost of risk-less debt. But, since he explicitly references to Ruback (1986), it has to be assumed that he bases his approach on Ruback's (1986) rate.
} 


\subsection{Derivation of Discount Rates}

Next, Ruback's (1986) assumptions will be assigned. There are three central assumptions for Ruback to derive the after-corporate-tax risk-free rate. First, it has to be stressed that Ruback's discount rate applies to after-tax cash flows. This assumption is no restriction which has to be resolved, since step-up induced depreciation benefits are after-tax flows, too. Every additional dollar of step-up induced depreciation tax shield increases the after-tax cash flow of a firm by one dollar, as it reduces the tax burden by one dollar. Accordingly, the depreciation benefits to be analyzed, namely those that are asset step-up induced, fit into Ruback's framework. Next, Ruback hypothesizes that the cash flows to be valued are entirely financed with debt. ${ }^{32}$ Finally, he assumes that these cash flows are risk-less streams. Both latter assumptions are not realistic for step-up induced depreciation tax shields. Hence, this paper proceeds by resolving these two restrictive assumptions and applying a more realistic framework towards step-up induced depreciation tax benefits.

Initially, we address the fact that depreciation benefits are not entirely financed with debt. Those benefits, as any other corporate cash flow, are usually levered. To analyze the effect on the discount rate we introduce a case differentiation. Case 1 refers to a valuation of the step-up induced depreciation benefit in the context of an Adjusted Present Value approach. The APV formula quantifies the contribution of debt tax shields to firm value in a separate term. The operating business is treated as being unlevered (as valued via the first term in the APV). This also holds true for the step-up induced tax shields to be valued in the third term. Due to the fact that the debt tax benefit is already accounted for in the second term of the APV-Formula, Ruback's after-corporate-tax risk-less discount rate has to be modified to the risk-free rate. Such a proceeding regarding the valuation of depreciation tax shields in the context of adjusted present valuation is also promoted by Tirtiroğlu (1998), who assumes these benefits to be free of risk. ${ }^{33}$ Case 2 refers to a standalone valuation of the step-up induced depreciation tax shield. Since leverage has to be accounted for in this case, the corresponding tax benefit can be realized according to the corresponding leverage ratio. We assume that the tax shield is levered to the same extent as the entire corporation. Note that the leverage ratio of the combined entity (after the acquisition) has to be considered in this context. Although the depreciation step-ups to be evaluated are entirely derived via the assets of the target, those tax benefits are realized by the combined entity in the periods after the acquisition. In corporate valuation, target leverage ratios are usually utilized instead of current leverage ratios in the context of estimating discount rates. ${ }^{34}$ While target capital structures of firms are normally aimed to be met by no longer than three to five years, most assets are depreciated over a significantly longer schedule. Accordingly, a part of the step-up induced depreciation benefits is realized after the target ratio is met, while the remainder is realized when the target ratio is partially met. Concluding, the target leverage ratio is a better proxy for the valuation of depreciation benefits than the current leverage ratio. When anticipated shifts in corporate capital structure are material, it is more efficient to use an APV approach for valuation of depreciation benefits. According to the rationale above, the formulas for the depreciation tax shield's discount rate $r_{D T S}$ for the two cases are as follows:

\footnotetext{
${ }^{32}$ As also noted by Sick (1990), p. 1438.

${ }^{33}$ See Tirtirolu (1998), p. 299, Formula 1b.

${ }^{34}$ Copeland, Koller, and Murrin (2000), p. 203.
} 
$r_{D T S}=r_{D T S}{ }^{\prime}(A P V)=r_{f}$

$r_{D T S}=r_{D T S}{ }^{\prime}(s t a n d a l o n e)=l_{t c e}(1-\tau) r_{f}+\left(1-l_{t c e}\right) r_{f} \quad$ for stand-alone valuations

where:

$l_{\text {tce }}=$ The target leverage ratio of the combined entity after the acquisition

Next, we address the second assumption, which presumes depreciation tax benefits to be certain flows. In practice, neither the firm's general depreciation benefits nor special, asset step-up induced depreciation benefits are totally free of risk. General depreciation tax shields depend on the level of depreciable/amortizable assets and can vary significantly due to the volatility of investments in depreciable assets. These variations are not predictable. Moreover, realizable special and general depreciation tax shields vary unpredictably depending on the levels of corporate tax rates and corporate profits. The following paragraphs first describe which sources of uncertainty persist for step-up based depreciation tax shields, and thereon show how the discount rates of Equations (3) and (4) have to be further adjusted to account for these uncertainties. Bodington (2003) also classifies depreciation benefits as being not free of risk. He points out that, in his experience, sellers and buyers of assets discount such flows at a riskadjusted rate. ${ }^{35}$

Before assigning relevant uncertainties to the discount rate, it is essential to discuss their character. There are four important uncertainties inherent in step-up based depreciation benefits: default risk, an uncertainty regarding the usability of the shields, an uncertainty concerning changing corporate marginal tax rates, and the acquirer's difficulty in assessing the temporal distribution of the asset step-up induced depreciation benefits ex ante. The most obvious source of uncertainty is default risk. As firms may go out of business, it is uncertain whether future depreciation benefits resulting from an asset step-up can be realized. Secondly, there is the risk that firms are not able to use the entire amount of the tax shield immediately (hereafter also referred to as the uncertainty of tax shield usability). There are several aspects of the tax code driving this uncertainty. For example, in the case of negative taxable income, a certain portion of corporate tax shields, and thus also a certain portion of step-up induced depreciation benefits, cannot be utilized to shield taxes from gross income in the current period. Due to tax loss carryforwards and carrybacks, this negative taxable income, also referred to as net operating loss (NOL) ${ }^{36}$, can be utilized to shield gross income in other periods. Under current United States tax law, net operating losses can be carried forward up to twenty years and carried back up to two years to reduce taxable income in those years. Correspondingly, carryforwards and carrybacks result in lower tax shields at present and in higher tax shields in the future (namely, the period into which the unused shield is carried forward) and in the past. It is clear that firms usually generate positive levels of taxable income, meaning they are utilizing all of their tax shields. But the fact that in economic downturns a good proportion of

\footnotetext{
${ }^{35}$ As mentioned by Bodington (2003), p. 230, Footnote 17.

${ }^{36}$ See Scholes, Wolfson, Erickson, Maydew, and Shevlin (2005), p. 340.
} 
firms is often generating taxable losses proves that this source of uncertainty is realistic and has to be included into the valuation of depreciation tax shields.

Other factors possibly altering the usability of depreciation tax shields are the alternative minimum tax and the amount of other corporate tax shields such as interest tax shields. Another component of the tax shield which contributes to its uncertainty is the marginal tax rate, ans its volatility (hereafter also referred to as the tax rate risk). As discussed in the previous section, the marginal tax rate is often estimated via the statutory corporate tax rate. In his empirical study, Kaplan (1989) also identifies the latter two uncertainties in the context of valuing step-up induced depreciation tax shields as uncertainties increasing the corresponding discount rate. ${ }^{37}$ Moreover, the uncertainty of tax shield usability has been mentioned by Schipper and Smith (1991) in the context of valuing step-up induced depreciation benefits. ${ }^{38}$

The final source of risk for the depreciation tax shield is the uncertainty regarding the temporal distribution of the asset step-up induced depreciation benefits. As described in Section 3 it is straightforward to derive the absolute amount of asset step-up. It is much more difficult to estimate how the step-up amount is allocated among the different asset classes, in particular for outsiders. Whether an asset is classified as I.R.C. Section 197 intangible (Asset Classes VI and VII) or as belonging to another asset class determines whether the related stepped up amount is amortized linearly over 15 years or depreciated according to the respective depreciation schedule. This problem is also documented by Schipper and Smith (1991) in their analysis of depreciation deductions for management buyouts. ${ }^{39}$ Another complexity in this context is the age of the acquired assets. The age is the determinant for the depreciation schedule which, in turn, affects the temporal distribution of the step-up induced depreciations. Summarizing this descriptive paragraph, note that default risk and the uncertainty of usability only evolve downside potential for the value of the total shield, while the other two sources of uncertainty include both downside as well as upside potential.

Next, these sources of uncertainty are to be assigned and incorporated into the discount rate. First, we consider the uncertainty of usability. As per the definition, the marginal tax rate includes the uncertainty of tax shield usability, since it is defined via the present value of current and expected future cash flows paid to tax authorities due to earning one additional dollar of taxable income. ${ }^{40}$ However, the need to consider the uncertainty of usability is dependent upon which measure for the marginal tax rate is used. When the statutory tax rate is utilized, this risk has to be additionally incorporated into the discount rate, since, e.g., possible negative taxable incomes in combination with tax-loss carryforwards and carrybacks are not accounted for. We recommend using Graham's simulated tax rates. The reason is that Graham (1996b) concludes that simulated tax rates are the best proxy for the marginal tax rate. ${ }^{41}$

Schipper and Smith (1991) emphasize that it is fundamental to have a good proxy for the marginal tax rate. They state that the marginal tax rate is a key determinant between tax benefits and tax deductions in the framework of increased depreciation deductions achieved by step-ups. In contrast to statutory tax rates, Graham's simulated tax rates do account for the

\footnotetext{
${ }^{37}$ See Kaplan (1989), p. 620.

${ }^{38}$ See Schipper and Smith (1991), p. 298.

${ }^{39}$ See Schipper and Smith (1991), p. 297.

40 See e.g., Shevlin (1990), p. 51; Graham (1996b), p. 190, or Scholes, Wolfson, Erickson, Maydew, and Shevlin (2002), p. 157.

${ }^{41}$ See Graham (1996b), p. 189.
} 
uncertainty of tax shield usability. Based on the work of Shevlin (1990), Graham (1996a) derives the marginal corporate tax rate via simulation. His simulative proceeding in particular accounts for the following aspects: uncertainty about the level of taxable income, the progressivity in the corporate statutory tax code, net operating loss carrybacks and carryforwards, state, local and foreign taxes, tax credits, the alternative minimum tax and the level of financing and investment related tax shields. According to Graham's approach, taxable income (while being assumed to follow a random pattern) is simulated to account for all periods in which carrybacks and carryforwards can occur. After adding a single dollar of taxable income the present value of marginal taxes is determined, i.e., with the possibility of carrybacks and carryforwards, etc., being accounted for. Each simulation provides an estimate, and the average of all simulations is taken as a proxy for the marginal tax rate. ${ }^{42}$ Admittedly, Graham did not derive his simulated tax rate exclusively for calculating step-up induced depreciation benefits, but for determining a proxy for the marginal tax rate of a firm. Therefore, we have to discuss whether his simulated tax rate is also an appropriate multiplier for the (stepup induced) enhanced depreciation amount. This is certainly the case if all aspects that are included in the derivation of the simulated tax rates, which have an impact on the level of taxes effectively paid by the firm, also have an impact on the value of the depreciation benefit. Analyzing Graham's incorporated aspects it can be argued that the inclusion of tax credits, which does not have an effect on the value of asset step-up induced depreciation, is possibly lowering the corporate tax burden and thus the marginal tax rate. ${ }^{43}$ The fraction of the respective depreciation effectively shielding taxes is not altered by tax credits, since tax credits can only be used if taxable income and the resulting gross tax (as calculated via taxable income times the statutory tax rate) are positive. In such a case the depreciation can be fully used to shield taxes irrespective of the level of tax credits. Amounts of (non-refundable) tax credits that exceed the gross tax liability can be carried forward. All other aspects included by Graham affect the value of the step-up induced depreciation benefits. Those aspects can either alter the portion of step-up induced depreciation effectively shielding taxes, and thus have an impact on the usability of depreciation tax shield (uncertainty about the level of taxable income, net operating loss carrybacks and carryforwards, the alternative minimum tax and the level of financing and investment related tax shields), or can have an effect on the value of the depreciation benefit via the statutory tax rules (the progressivity in the corporate statutory tax code and state, local and foreign taxes). ${ }^{44}$

Altogether, the simulated tax rate has to be considered an appropriate multiplier for asset stepup based depreciation, as only one out of all seven included aspects is not relevant for the valuation of step-up induced depreciation benefits. Concluding, by using the simulated marginal tax rate as a multiplier for depreciation, we are able to include all aspects driving the uncertainty of tax shield usability. Graham's (1996a) simulated tax rates are broadly utilized in

\footnotetext{
${ }^{42}$ For more details regarding the calculation of the simulated marginal tax rate refer to Graham (1996a). Graham's sample file, in which he provides proxies for the corporate marginal tax rate for after-interest and pre-interest income for over 10,000 firms from 1980-present, can be ordered online via.

http://faculty.fuqua.duke.edu/ jgraham/taxform.html.

43 See Graham and Lemmon (1998), p. 58.

${ }^{44}$ Please refer to Graham and Lemmon (1998), p. 56 for a more detailed description of the aspects included into the simulation.
} 
academic research ${ }^{45}$ Based on the use of this simulated marginal tax rate, no further adjustment of the discount rate has to be carried out when incorporating the uncertainty of tax shield usability. Correspondingly, the next intermediate result for the valuation of step-up induced depreciation benefits is as follows:

$V_{D T S}=\sum_{t=1}^{T} \frac{\tau_{m} S U D_{t}}{\left(1+r_{D T S}\right)^{t}}$

where:

$r_{D T S}=r_{D T S}{ }^{\prime \prime}(A P V)=r_{f} \quad$ for APV-based valuations

$r_{D T S}=r_{D T S} "(s$ tandalone $)=l_{t c e}\left(1-\tau_{m}\right) r_{f}+\left(1-l_{t}\right) r_{f} \quad$ for stand-alone valuations

where:

$V_{D T S}=\quad$ The value of step-up induced depreciation tax benefits

$\tau_{m} \quad=\quad$ The (simulated) marginal tax rate of the combined entity

$S U D=$ The amount of step-up induced depreciation

Note that the marginal tax rate to be used has to be the marginal rate of the combined entity after the acquisition. The rationale is concordant with the previous section when discussing the appropriate leverage ratio.

Next, the tax rate risk has to be allocated. For this purpose we have to analyze the volatility of Graham's simulated tax rates, since we promote the use of these rates as a measure for the marginal tax rate. In the previous paragraph we described the aspects that influence the derivation of Graham's simulative tax rates. As these aspects are the determinants of the simulated marginal rate, it is their volatilities which ultimately drive tax rate volatility. Thus, their volatilities are to be analyzed next. Since, in Graham's approach, taxable income is simulated to derive the marginal tax rate, the corresponding volatility is already accounted for and may not be considered again. Other volatility drivers have to be examined.

Looking at Graham's tax rate determinants, it turns out that changes in the corporate statutory tax code, state, local and foreign taxes, modifications of the regulations regarding net operating loss carrybacks and carryforwards, and revisions of the alternative minimum tax code, are potential sources of uncertainty that have to be considered. ${ }^{46}$ Note that all potential sources are

\footnotetext{
45 On page 65 of their study of the measurement of corporate tax rates, Graham and Lemmon (1998) reference several other papers that use simulated tax rates to analyze incentives for firms provided by the tax code.

46 The remaining two determinants of Graham's discount rate do not have to be considered. Tax credits are independent from tax benefits and the level of financing and investment related tax shields is a determinant of taxable income.
} 
based on changes in corporate tax laws, but such changes occur rather infrequently. When comparing the frequency of changes of the corporate tax law with the frequency of changes in the level of corporate debt or security prices, it becomes evident that the volatility arising from changes in tax laws is of secondary importance. For example, in the last 50 years there have only been nine changes of top statutory tax rates for ordinary income of $\mathrm{C}$ corporations (the most important tax variable for firms). Furthermore, such changes, if they occur, do not usually alter the tax rate extraordinarily. Summarizing, no adjustment of the discount rate for step-up induced depreciation tax shields needs to be undertaken. Equations (5) - (7) remain unchanged.

The next source to be introduced is default risk. Default risk is priced by a credit spread. However, increasing the risk-free rates of Equations (6) and (7) up to the cost of debt would be an exaggeration, since default risk for debt and interest payments is higher than for depreciation tax shields. The rational is as follows: when calculating credit spreads, lenders have to include two scenarios; the debtor filing for bankruptcy protection under Chapter 7 or Chapter $11 .{ }^{47}$ Under these scenarios the lender may either lose all or only parts of his claim. Hence, the corresponding risk premium will reflect this expectation. For depreciation benefits, this issue is different. If a firm files for Chapter 11 and manages to escape from bankruptcy after the reorganization, the value of its tax shields can be (partially) saved via tax loss carryforwards. Since the profitability shifts occurring during the reorganization are accounted for in Graham's simulated tax rates, the default risk of successful Chapter 11 reorganizations is already considered via the uncertainty of tax shield usability and may not be included in the default risk premium once more. After that, only the risk that the respective firm might eventually go out of business by ceasing operations has to be considered. When a corporation is liquidated, the value of all tax attributes vanishes. According to the rational above, default risk involved for principal and interest payments is slightly more extensive than default risk for depreciation tax shields. Correspondingly, the risk-free rates of Equations (6) and (7) have to be increased, but not to the full extent up to the cost of debt. Therefore, the new rate $r^{*}$ is between the cost of debt and the risk-free rate. Since in the United States Chapter 7 filings are more frequent than Chapter 11 filings, and due to the fact that not every Chapter 11 yields a successful reorganization, we note that $\mathrm{r}^{*}$ is closer to the cost of debt than to the risk-free rate. Accordingly Equations (6) and (7) change to:

$$
\begin{array}{ll}
r_{D T S}=r_{D T S}(A P V)=r^{*} & \text { for APV-based valuations } \\
r_{D T S}=r_{D T S}(\text { standalone })=l_{\text {tce }}\left(1-\tau_{m c e}\right) r^{*}+\left(1-l_{t c e}\right) r^{*} & \text { for stand-alone valuations }
\end{array}
$$

where:

$r_{f}<r^{*}<r_{d}$

$r_{d} \quad=\quad$ The cost of debt of the combined entity

\footnotetext{
47 A filing with a federal bankruptcy court for bankruptcy protection under Chapter 7 results in a cessation of operations for the business. The firm sells all its assets and distributes the proceeds to its creditors. In case of a Chapter 11 filing the firm tries to stay in business. While the court is overseeing the corresponding reorganization, it can authorize complete or partial relief from the firm's debt obligations.
} 
When determining $\mathrm{r}^{*}$, the financial analyst has to bear in mind that cost of debt of the combined entity after the acquisition has to be considered in this context.

Finally, we take a look at the fourth source of uncertainty, the uncertainty regarding the temporal distribution of the additional depreciations. Knowledge of this temporal distribution is simply a question of data availability. While for deal outsiders it is rather difficult to obtain sufficient information for reliable estimates, the situation is different for potential acquirers in their due diligence process. As Maydew et al. (1999) mention, their discussions with M\&A professionals indicate that step-up induced depreciation benefits arising in the context of asset deals are determined by target firms, because they are regarded as an integral part of the acquisition price. Moreover, these benefits are even outlined in the sales materials provided to the potential buyers. Accordingly, this uncertainty is not expected to be material for due diligence insiders and hence, not accounted for in our approach.

\subsection{Results}

Before summarizing our essays on the derivation of discount rates for step-up induced depreciation benefits, we also have to consider possible interdependencies of the relevant uncertainties. Fortunately, the examination of interdependencies is straightforward in the context of our analysis. Since tax rate risk is negligible, and we assume that there is no uncertainty about the temporal distribution of the additional depreciations, the problem narrows to the interdependency between the uncertainty of the usability of the tax shields and default risk. ${ }^{48}$ Actually, the interdependence does not matter, since the two effects are considered separately via two different variables (and not via two parallel, fixed premiums on Ruback's discount rate): default risk is incorporated via a premium on the risk-free rate while usability uncertainty is accounted for by means of Graham's (1996a) marginal tax rate.

Summarizing the approach to deduce an appropriate discount rate for the valuation of asset stepup induced depreciation benefits, we first recommend using Graham's simulated corporate tax rates as a measure for the marginal tax rate. Second, we refer to a discount rate as per equations (8) and (9) in the framework of equation (5). The discount rates $r_{D T S}$ (APV) and $r_{D T S}$ (standalone) can easily be calculated by corporate insiders, as all relevant parameters should commonly be available for the respective financial planners, as are Graham's simulated tax rates.

Table 1 shows the comparison of the discount rates for step-up induced depreciation tax shields, as utilized by empirical studies evaluating depreciation benefits, with the corresponding rates derived by our approach. For each discount rate derived by the empirical studies introduced in Section 2, the rates $r_{D T S}(A P V)$ and $r_{D T S}$ (standalone) are calculated based on the average risk-free rate of the corresponding period of the analysis. The rates as used in the empirical studies in each case refer to a relatively large subset of firms; they are not companyspecific. Correspondingly, the derivation of $r_{D T S}(A P V)$ and $r_{D T S}$ (standalone) for Table 1 is not company-specific either, but an economy-wide assessment. It shall be a measure for the respective company subset. Pursuant to our rationale of default risk incorporation, we add three quarters of the average risk premium for investment grade corporate debt onto the average riskfree rate to derive $r^{*}$. The average risk premium for investment grade corporate debt, to be added onto the yield to maturity of US 10 -Year Treasury Bonds, is approximately $2 \%$ for bond

\footnotetext{
${ }^{48}$ Indeed a positive correlation has to be assumed. The higher the volatility of corporate profits the higher both uncertainties become. Admittedly, the profitability volatility is not the only driver for default risk and the uncertainty of usability; however it is certainly an important driver for both risks.
} 
ratings around $\mathrm{BBB}$ and $\mathrm{BB} .{ }^{49}$ Concerning the calculation of the standalone discount rate, a few more assumptions are required. Regarding the leverage ratios, we refer to Liu (2005). She finds debt/equity ratios declining from 45\% in 1980 to approximately one third in $2000 .{ }^{50}$ The marginal tax rate can vary significantly among industries, firms, and periods. Since a relatively big sample of companies is involved for each of the mentioned studies, it seems fair to estimate the average marginal corporate tax rate for each period of analysis via annual averages calculated from Graham's entire sample of simulated tax rates for pre-interest income, which includes more than 10,000 firms.

As all of the mentioned studies in Table 1 estimate the step-up induced depreciation tax shield via stand-alone valuation, we have to compare the rates used in those studies with $r_{D T S}$ (standalone). It stands out that, except for Kaplan (1989) and Schipper and Smith (1991), all studies use relatively high discount rates compared to our calculations. A possible reason for this pattern is that those studies by the majority use statutory tax rates when valuing the depreciation benefits. Accordingly, they have to additionally incorporate the uncertainty of tax shield usability into the discount rate, probably increasing the rate.

The discount rates used in literature so far are estimated in a rather vague manner, i.e., via ranges or alternative rates that vary significantly. Moreover, these rates are not derived, but chosen arbitrarily. This paper contributes to financial research related to corporate acquisitions via a comprehensive discussion of all relevant parameters influencing the discount rates for the valuation of step-up induced depreciation benefits and by deriving a pricing formula.

\footnotetext{
${ }^{49}$ See Copeland, Koller, and Murrin (1999), p. 212.

${ }^{50}$ Estimates for market leverage are taken from Liu (2005), Table 2. Liu (2005) calculates leverage ratios from 1980 to 1999 for all firms that appear on the Compustat database and whose IPO date could be identified.
} 


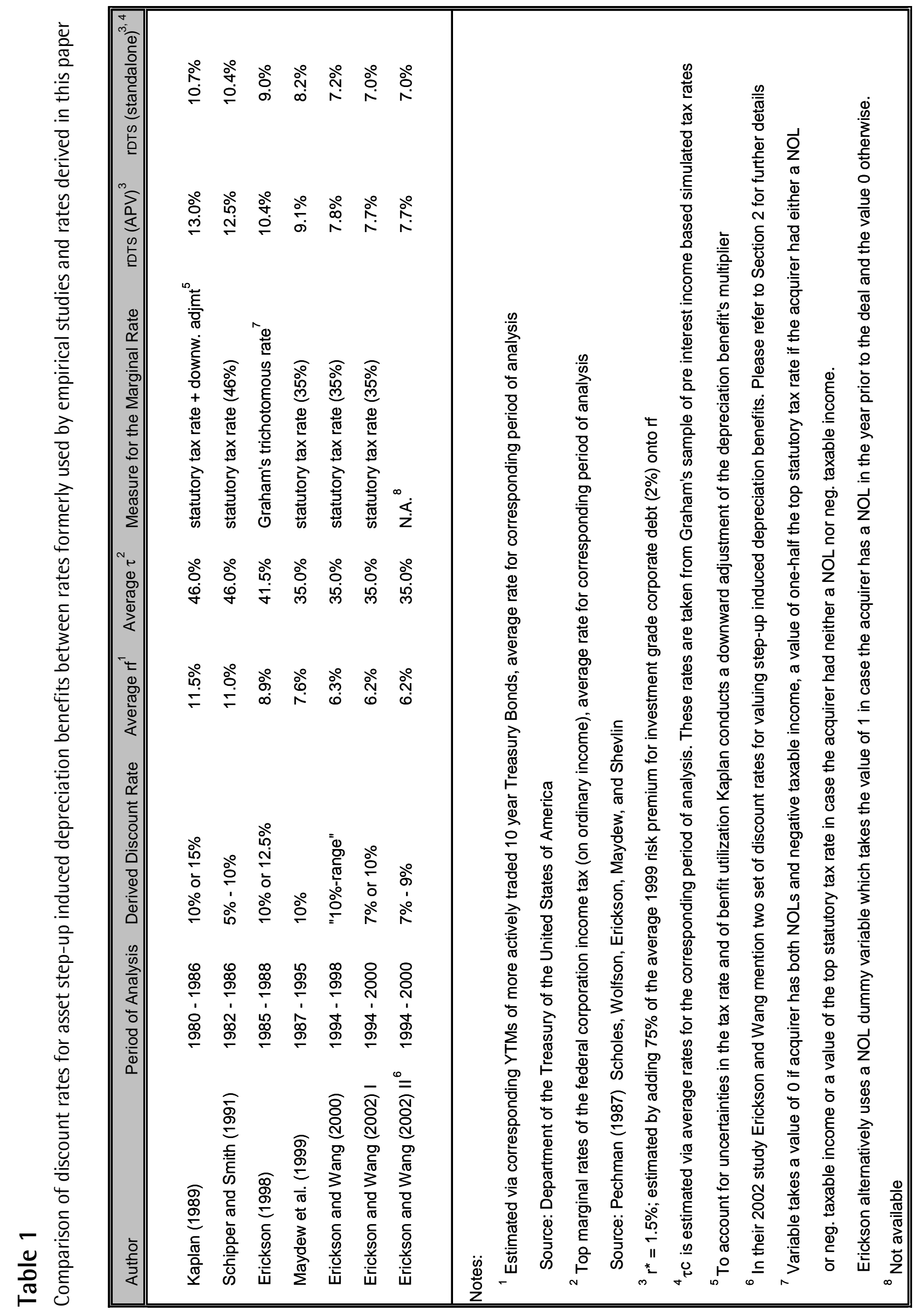




\section{Summary and Conclusion}

This paper discusses the relevant parameters and introduces an approach to derive discount rates for asset step-up induced depreciations and amortizations created in the context of corporate mergers and acquisitions. Academic research in corporate finance does not provide a consistent approach towards the valuation of step-up induced depreciation and amortization tax shields. Specifically, a model of how to determine adequate discount rates for these tax shields cannot be found. While some empirical studies, which examine tax benefits in the framework of corporate acquisitions, use specific rates to discount the value of these depreciation and amortization benefits, corresponding analyses and derivations are notably short. The rates are determined arbitrarily, not via analysis. Hence, this paper contributes by deducting particular discount rates for the valuation of such benefits via an integrated approach. By including all relevant sources of uncertainty for asset step-up induced tax shields and by accounting for corporate debt financing, we show that for APV valuations $r^{*}$, a rate between the firm's cost of debt and the risk-free rate, is adequate to discount step-up induced depreciation and amortization benefits. For standalone valuations, the adequate discount rate is the after-tax weighted average of $r^{*}$. When applying these rates, Graham's (1996a) simulated marginal tax rates have to be utilized, accounting for the uncertainty of tax shield usability. Moreover, this paper compares these rates with the rates determined arbitrarily in empirical research on the valuations of tax shields of step-up induced depreciations. It becomes evident that the rates used in these studies are in line with the general results derived in this paper. 


\section{References}

Auerbach, Alan J. and Reishus, David (1986), "Taxes and the Merger Decision: An Empirical Analysis,” NBER Working Paper No. 1855.

Bittker, Boris I. and Eustice, James S. (2000), "Federal Income Taxation of Corporations and Shareholders," $7^{\text {th }}$ edition, New York, Warren, Gorham \& Lamont.

Bodington, Jeffrey C. (2003), "Discount Rates for Consistent Valuation of Various Measures of Book Income and Cash Flow,” The Appraisal Journal (July, 2003), pp. 228-236.

Copeland, Thomas E., Koller, Tim, and Murrin, Jack (2000), "Valuation - Measuring and Managing the Value of Companies," $3^{\text {rd }}$ edition, New York: John Wiley \& Sons, Inc.

Erickson, Merle (1998), "The Effect of Taxes on the Structure of Corporate Acquisitions," Journal of Accounting Research, Vol. 36, No. 2, pp. 279-298.

Erickson, Merle and Wang, Shiing-wu (2000), "The Effect of Transaction Structure on Price: Evidence from Subsidiary Sales," Journal of Accounting and Economics, Vol. 30, pp. 59-97.

Erickson, Merle and Wang, Shiing-wu (2005), "The Effect of Organizational Form on Acquisition Price," Capital Ideas, Vol. 3, No. 3 (Winter 2002), University of Chicago Press.

Freeland, James J., Lathrope, Daniel J., Lind, Stephen A., and Stephens, Richard B. (2004), "Fundamentals of Federal Income Taxation," $13^{\text {th }}$ edition, New York: Thomson West.

Ginsburg, Martin D. and Levin Jack S. (2001), "Mergers, Acquisitions and Buyouts - A Transactional Analysis of the Governing Tax," Legal and Accounting Considerations, Aspen Publishers.

Graham, John R. (1996a), “Debt and the Marginal Tax Rate," Journal of Financial Economics, Vol. 41, pp. 41-73.

Graham, John R. (1996b), "Proxies for the Corporate Marginal Tax Rate," Journal of Financial Economics, Vol. 42, pp. 187-221.

Graham, John R. and Lemmon Michael L. (1998), "Measuring Corporate Tax Rates and Tax Incentives: A New Approach,” Journal of Applied Corporate Finance, Vol. 11, No. 1, pp. 54-65.

Inselbag, Isik and Kaufold, Howard (1989), "How to Value Recapitalizations and Leveraged Buyouts," Journal of Applied Corporate Finance, Vol. 2, No. 2, pp. 87-96.

Inselbag, Isik and Kaufold, Howard (1997), "Two DCF Approaches for Valuing Companies under Alternative Financing Strategies" (and how to Choose Between them), Journal of Applied Corporate Finance, Vol. 10, No. 1, pp. 114-122.

Kaplan, Steven N. (1989), "Management Buyouts: Evidence on Taxes as a Source of Value," The Journal of Finance, Vol. 44, No. 3, pp. 611-632.

Liu, Laura Xiaolei (2005), "Do Firms Have Target Leverage Ratios? Evidence from Historical Market-to-Book and Past Returns," University of Rochester Working Paper.

Locke, Stuart M (1990), "Property Investment Analysis Using Adjusted Present Values," The Appraisal Journal, July, pp. 373-378. 
Luehrman, Timothy A. (1997), “What's it Worth? A General Manager's Guide to Valuation," Harvard Business Review (May-June), pp. 132-142.

Maydew, Edward L./Schipper, Katherine/Vincent, Linda (1999): "The Impact of Taxes on the Choice of Divestiture Method," Journal of Accounting and Economics, Vol. 28, pp. 117-150.

Myers, Stewart C. (1974), "Interactions of Corporate Financing and Investment Decisions Implications for Capital Budgeting,” Journal of Finance, Vol. 39, pp. 1-25.

Pechman, Joseph (1987), “Federal Tax Policy,” Washington, DC, Brookings Institution

Ruback, Richard S. (1986), "Calculating the Market Value of Risk-less Cash Flows," Journal of Financial Economics, Vol. 15, pp. 323-339.

Schipper, Katherine and Smith Abbie (1991), "Effects of Management Buyouts on Corporate Interest and Depreciation Tax Deductions," Journal of Law \& Economics, Vol. 34, pp. 295-341.

Scholes, Myron S., Wolfson, Mark A., Erickson, Merle, Maydew, Edward L., and Shevlin Terry (2002), "Taxes and Business Strategy - A Planning Approach," $2^{\text {nd }}$ edition, New Jersey: Prentice Hall.

Scholes, Myron S., Wolfson, Mark A., Erickson, Merle, Maydew, Edward L., and Shevlin Terry (2005), "Taxes and Business Strategy - A Planning Approach," $3^{\text {rd }}$ edition, New Jersey: Prentice Hall.

Shevlin, Terry (1990), "Estimating Corporate Marginal Tax Rates with Asymmetric Tax Treatment of Gains and Losses," Journal of American Taxation Association, Vol. 12, pp. 51-67.

Sick, Gordon A. (1990), “Tax-Adjusted Discount Rates," Management Science, Vol. 36, No. 12, pp. 1432-1450.

Tirtiroğlu, Doğan (1998), "Property Investment Analysis Using Adjusted Present Values: Modifications,” The Appraisal Journal (July), pp. 298-304. 